\title{
USŁUGI ŚWIADCZONE W INTERESIE OGÓLNYM JAKO ELEMENT EUROPEJSKIEGO MODELU SPOŁECZNEGO
}

\section{Wstęp}

Jednym z działań o komplementarnym - w stosunku do procesu budowania spójności gospodarczej i terytorialnej Unii Europejskiej (UE) - charakterze jest wspieranie spójności społecznej. Wynika to z art. 4 ust. 2 lit. c Traktatu o funkcjonowaniu Unii Europejskiej z dnia 13 grudnia 2007 r. ${ }^{1}$, przesądzającego, że spójność gospodarcza, społeczna oraz terytorialna to dziedzina stanowiąca kompetencję (współ)dzieloną pomiędzy UE i państwa członkowskie tworzące tę organizację międzynarodową ${ }^{2}$ Z tego punktu widzenia jest oczywistym, że dla wielu działań o doniosłości prawnej i politycznej, realizowanych zarówno na poziomie unijnym, jak i w tworzących tę organizację państwach, ważnym punktem odniesienia będzie funkcjonowanie europejskiego modelu społeczno-gospodarczego, wraz z poszczególnymi tworzącymi go instytucjami.

W tym kontekście na szczególną uwagę zasługuje kwestia zapewnienia wszystkim obywatelom UE powszechnego i sprawiedliwego dostępu do pewnych podstawowych usług. Chodzi tu o usługi, które zaspokajają niezwykle ważne potrzeby obywateli. W prawodawstwie unijnym, w tym także w dokumentach politycznych, przyjmowanych przez poszczególne instytucje UE, usługi te określa się mianem „usług świadczonych

* Dr hab., prof. Uniwersytetu Szczecińskiego, radca prawny; e-mail: Daniel.Wacinkiewicz @usz.edu.pl, ORCID ID: https:/ / orcid.org/0000-0002-5048-9866.

1 Traktat o funkcjonowaniu Unii Europejskiej (wersja skonsolidowana), Dz. Urz. UE C 326 z 26.10.2012, s. 47-200 (dalej: TFUE).

2 Na temat statusu prawnego Unii Europejskiej zob. E. Cała-Wacinkiewicz, Charakter prawny Unii Europejskiej w świetle prawa międzynarodowego, Warszawa 2007. 
w interesie ogólnym" (services of general interest). Problematyka dotycząca ich od wielu lat znajdowała się w centrum debaty poświęconej europejskiemu modelowi społeczeństwa i stanowiła zarazem ważny kontekst poszukiwań odpowiedzi na pytanie o rolę UE w kształtowaniu przyszłości usług użyteczności publicznej in genere ${ }^{3}$.

Prawne ramy usług publicznych w Europie przeszły istotną transformację. W jej rezultacie ukształtowało się przekonanie, że wysokiej jakości usługi publiczne są istotne nie tylko dla konsumentów, ale stanowią również niezwykle istotny element europejskiego modelu społecznego.

Można stwierdzić, że dostęp do usług świadczonych w interesie ogólnym zwiększa spójność i integrację społeczną, tworząc zarazem podstawy do godnego życia. W istocie jednak, w zapewnieniu dostępu do tych usług, uwidacznia się coś więcej - coś, czego źródeł możemy upatrywać w fundamentalnych wartościach, na których oparte zostały, początkowo Wspólnoty Europejskie, obecnie zaś Unia Europejska. Chodzi tu o równe traktowanie wszystkich obywateli UE, o poszanowanie ich praw i o zapewnienie sprawiedliwości.

Pomimo kluczowej roli, jaką w europejskim modelu społeczno-gospodarczym odgrywa problematyka usług świadczonych w interesie ogólnym, nadal wiele istotnych kwestii - dotyczących ich zakresu, charakteru, sposobu zorganizowania czy też oceny funkcjonowania - wywołuje daleko idące rozbieżności oraz kontrowersje. Wciąż także brak jest podstaw do uznania, że mamy do czynienia $\mathrm{z} \mathrm{w}$ pełni ukształtowaną instytucją. Stan ten, skłania do wielopłaszczyznowych badań tytułowej problematyki, a z takiego nastawienia badawczego wynikają co najmniej dwa ważne problemy, warte naukowej analizy, która będzie przedmiotem niniejszego opracowania.

3 Przyjęcie przez Komisję Europejską najpierw Zielonej księgi na temat usług użyteczności publicznej (Bruksela, dnia 21 maja 2003 r., COM(2003) 270,) a następnie Białej księgi nt. usług użyteczności publicznej (Bruksela, dnia 12 maja 2004 r., COM(2004) 374 wersja ostateczna; dalej: Biała księga) podyktowane było uznaniem ogromnej roli i znaczenia „poprawnie funkcjonujących, łatwo dostępnych, wysokiej jakości, przystępnych cenowo usług użyteczności publicznej dla jakości życia obywateli Europy, ochrony środowiska oraz konkurencyjności europejskich przedsiębiorstw", Biała księga, s. 3. Wśród istotnych elementów debaty politycznej poświęconej tej problematyce w kolejnych latach należy zwrócić uwagę m.in. na: Założenia polityczne dla następnej Komisji, sformułowane w Brukseli dnia 3 września 2009 r. przez Przewodniczącego Komisji Europejskiej. 
Pierwszym z nich, jest ustalenie wiążącego sposobu rozumienia pojęcia usług świadczonych $\mathrm{w}$ interesie ogólnym. Stwierdzenie, że usługi te stanowią swoistą konstrukcję prawa unijnego jest zaledwie wstępem do próby określenia sposobu ich pojmowania na gruncie obecnie wiążących regulacji prawnych. Następnie jako konieczne jawi się pytanie o rodzaj usług (bądź precyzyjniej kategorii usług), które można zakwalifikować jako usługi świadczone w interesie ogólnym. Rozwikłanie tej kwestii umożliwi zaś określenie ich podstawowych cech oraz ułatwi wskazanie, które z nich i w jakim zakresie, wywołują "skutki rynkowe”.

Drugim problemem jest ten na ile traktowanie usług świadczonych w interesie ogólnym, rozumianych jako kluczowy element europejskiego modelu społecznego, skłania do określenia szczególnych wymagań, związanych ze świadczeniem usług publicznych ${ }^{4}$ oraz ich specyficznych cech - postrzeganych zwłaszcza w kontekście oceny ich praktycznego funkcjonowania.

\section{Usługi świadczone $w$ interesie ogólnym jako kategoria zbiorcza}

Usługi świadczone w interesie ogólnym stanowią swoistą konstrukcję prawa unijnego. Nie posiada ona bezpośredniego odpowiednika w ustawodawstwie wewnętrznym poszczególnych państw członkowskich $^{5}$. Cechą charakterystyczną usług świadczonych w interesie ogól-

4 Problematyce zmieniających się uwarunkowań prawnych dotyczących usług publicznych poświęcone zostało opracowanie: M. Krajewski, J. van de Gronden, U. Neergaard (red.), The Changing Legal Framework for Services of General Interest in Europe. Between Competition and Solidarity, The Hague 2009. Ciekawą perspektywę analizy usług świadczonych w interesie ogólnym wyznacza opracowanie: M. Krajewski (red.), Services of General Interest Beyond the Single Market. External and International Law Dimensions, The Hague 2015. Ukazuje bowiem, że nieodłączne napięcie między ustanowieniem i zabezpieczeniem niezakłóconej konkurencji na rynkach a logiką usług publicznych istnieje nie tylko w prawie wewnętrznym Unii Europejskiej, ale również w międzynarodowym prawie gospodarczym. Ta perspektywa analiz, w której ważną rolę odgrywają kontrowersje dotyczące międzynarodowych umów handlowych, w istotny sposób przyczyniają się do toczącej się debaty na temat przyszłości usług świadczonych w interesie ogólnym w Unii Europejskiej.

5 Zob. K. Strzyczkowski, Prawo gospodarcze publiczne, Warszawa 2011, s. 286 i przywołana tam literatura. 
nym, jak i wchodzących w ich skład poszczególnych kategorii usług, jest celowe ich niedookreślenie $w$ prawodawstwie unijnym pozwalające ustawodawcom poszczególnych państw członkowskich na swobodę, co do definiowania i kwalifikowania określonych usług do poszczególnych kategorii 6 .

W prawodawstwie UE, gwarantowanie wysokiej jakości usług świadczonych w interesie ogólnym (a zwłaszcza usług świadczonych w ogólnym interesie gospodarczym) nie jest niczym nowym. Na gruncie obecnej regulacji prawnej (zwłaszcza po zmianach dokonanych mocą postanowień Traktu Lizbońskiego ${ }^{7}$ ) problematyka ta stanowi przedmiot regulacji art. $14^{8}$ oraz 106 ust. $2^{9}$ TFUE, a także - szczególnie istotnego z perspektywy niniejszych rozważań - Protokołu nr 26 do TFUE ${ }^{10} \mathrm{~W}$ sprawie usług świadczonych w interesie ogólnym. W tym kontekście na uwagę zasługują

6 Zob. H. Izdebski, Samorzad terytorialny. Podstawy ustroju i działalności, Warszawa 2011, s. 161-162.

7 Traktat z Lizbony zmieniający Traktat o Unii Europejskiej i Traktat ustanawiający Wspólnotę Europejską, sporządzony w Lizbonie dnia 13 grudnia 2007 r., Dz. U. z 2009 r. Nr 203, poz. 1569 (dalej: Traktat Lizboński).

8 Zgodnie z art. 14 TFUE (dawny art. 16 Traktatu ustanawiającego Wspólnotę Europejską (dalej: TWE): „bez uszczerbku dla artykułu 4 Traktatu o Unii Europejskiej i artykułów 93, 106 i 107 niniejszego Traktatu oraz zważywszy na miejsce, jakie usługi świadczone w ogólnym interesie gospodarczym zajmują wśród wspólnych wartości Unii, jak również ich znaczenie we wspieraniu jej spójności społecznej i terytorialnej, Unia i Państwa Członkowskie, każde w granicach swych kompetencji i w granicach stosowania Traktatów, zapewniają, aby te usługi funkcjonowały na podstawie zasad i na warunkach, w szczególności gospodarczych i finansowych, które pozwolą im wypełniać ich zadania. Parlament Europejski i Rada, stanowiąc w drodze rozporządzeń zgodnie ze zwykłą procedurą ustawodawczą, ustanawiają te zasady i określają te warunki, bez uszczerbku dla kompetencji, które Państwa Członkowskie mają, w poszanowaniu Traktatów, do świadczenia, zlecania i finansowania takich usług".

9 Z kolei art. 106 ust. 2 TFUE (dawny art. 86 TWE) przewiduje, że: „przedsiębiorstwa zobowiązane do zarządzania usługami świadczonymi w ogólnym interesie gospodarczym [...] podlegają normom Traktatów, zwłaszcza regułom konkurencji, w granicach, w jakich ich stosowanie nie stanowi prawnej lub faktycznej przeszkody w wykonywaniu poszczególnych zadań im powierzonych. Rozwój handlu nie może być naruszony w sposób pozostający w sprzeczności z interesem Unii".

10 Protokół nr 26 w sprawie usług świadczonych w interesie ogólnym, Dz. Urz. UE C 326 z 26.10.2012, s. 201-330 (dalej: Protokół nr 26). 
również postanowienia art. 36 Karty Praw Podstawowych ${ }^{11}$, dołączonej do Traktatu Lizbońskiego ${ }^{12}$.

Jak wspomniano, do kategorii „usług świadczonych w interesie ogólnym" odnosi się wprost Protokół nr 26, który podkreślając wagę tytułowych usług, zawiera istotne postanowienia wyjaśniające, odnoszące się zarówno do usług świadczonych w ogólnym interesie gospodarczym (art. 1), jak i do usług niemających charakteru gospodarczego świadczonych w interesie ogólnym (art. 2). Z treści art. 1 Protokołu nr 26 wynika, że wspólne wartości UE w odniesieniu do usług świadczonych w ogólnym interesie gospodarczym ${ }^{13}$ obejmują: po pierwsze, szeroki zakres uprawnień o charakterze dyskrecjonalnym, jaki przysługuje organom krajowym, regionalnym i lokalnym odnośnie do zlecania, organizowania oraz wykonywania usług świadczonych w ogólnym interesie gospodarczym. Istotnym jest tutaj, by wskazany zakres działań, odpowiadał potrzebom odbiorców w najpełniejszy sposób. To z kolei - po drugie - zakładać musi zróżnicowanie usług, o których mowa, uwzględniające m.in. różnorodność potrzeb i preferencji odbiorców (wynikające choćby z odmiennej sytuacji geograficznej, społecznej czy kulturowej). Po trzecie, wspólne wartości UE w odniesieniu do usług świadczonych w ogólnym interesie gospodarczym obejmują wysoki poziom jakości, bezpieczeństwa i przystępności cenowej, równe traktowanie oraz propagowanie powszechnego dostępu i praw odbiorców.

Z kolei, odnośnie do usług niemających charakteru gospodarczego świadczonych w interesie ogólnym, to zgodnie z art. 2 Protokołu nr 26, postanowienia traktatów nie naruszają kompetencji państw członkowskich w zakresie ich świadczenia, zlecania i organizowania. Co warte podkreślenia, przywołana regulacja oznacza, że kategoria usług określona $\mathrm{w}$ art. 2 Protokołu nr 26 nie podlega żadnym szczególnym unijnym

11 Kwestii usług świadczonych w ogólnym interesie gospodarczym, a precyzyjnie dostępności do nich poświęcony został także art. 36 Karty praw podstawowych Unii Europejskiej, stanowiąc, że: „Unia uznaje i szanuje dostęp do usług świadczonych w ogólnym interesie gospodarczym, przewidziany w ustawodawstwach i praktykach krajowych, zgodnie z Traktatami, w celu wspierania spójności społecznej i terytorialnej Unii". Wartym podkreślenia jest, iż Karta wyraźnie stanowi o ustawodawstwach i praktykach krajowych jako podstawie regulacji tym zakresie.

12 Karta praw podstawowych Unii Europejskiej, Dz. Urz. UE C 326 z 26.10.2012, s. 391-407.

13 W rozumieniu artykułu 14 TFUE. 
regulacjom prawnym i nie jest objęta traktatowymi przepisami, dotyczącymi rynku wewnętrznego i konkurencji. Nie oznacza to jednak, że usługi te nie będą podlegały ogólnym regulacjom traktatowym, co widać chociażby na przykładzie konieczności przestrzegania zasady niedyskryminacji przy określaniu sposobu organizacji usług niemających charakteru gospodarczego świadczonych $\mathrm{w}$ interesie ogólnym.

Niewątpliwą słabością postanowień Protokołu nr 26 jest nadanie im wyraźnie „interpretacyjnego" charakteru. Użycie w nim sformułowań takich jak np. „wysoki poziom jakości” czy „propagowanie powszechnego dostępu" implikuje wiele pytań, dotyczących ich mocy prawnej, charakteru i skutków prawnych ${ }^{14}$. Zapewne jest to jeden z czynników powodujących, że choć regulacje Protokołu nr 26 wykraczają poza zwykłą gwarancję wysokiej jakości dostępu do usług, to część z nich nie jest odpowiednio uregulowana, a co za tym idzie również nie jest wystarczająco wdrażana (w poszczególnych państwach członkowskich).

Na gruncie przywołanych powyżej regulacji prawnych skonstatować należy, że usługi świadczone w interesie ogólnym stanowią kategorię zbiorczą, do której przyjęło się kwalifikować różne usługi - zarówno świadczone w ogólnym interesie gospodarczym, jak i niemające charakteru gospodarczego (a świadczone w interesie ogólnym). Zasadnym staje się zatem pytanie, jakie szczegółowe kategorie usług, na gruncie obowiązujących regulacji prawnych, można zakwalifikować do usług świadczonych $\mathrm{w}$ interesie ogólnym?

W treści postanowień Protokołu nr 26 expressis verbis wskazana została pierwsza z nich - usługi świadczone w ogólnym interesie gospodarczym (services of general economic interest) ${ }^{15}$. Jest to niewątpliwie najbardziej eksponowana na gruncie prawodawstwa unijnego kategoria usług świadczonych w interesie ogólnym. To właśnie do nich odnoszą się w szczególności przywołane wcześniej art. 14 oraz art. 106 ust. 2 TFUE.

Usługami świadczonymi w ogólnym interesie gospodarczym są usługi podstawowe, realizowane w warunkach działalności gospodarczej, które służą interesowi publicznemu, stąd często $\mathrm{w}$ odniesieniu do nich

14 Zwraca na to uwagę Europejski Komitet Ekonomiczno-Społeczny w opinii w sprawie: Przystępność usług świadczonych w ogólnym interesie gospodarczym: definicja, pomiar, aspekty, inicjatywy europejskie, TEN/517, Bruksela, dnia 21 stycznia 2014 r., pkt 2.4, http:/ / www.eesc.europa.eu (dalej: Opinia TEN/517).

15 Na ten temat zob. C. Wehlander, Services of General Economic Interest as a Constitutional Concept of EU Law, The Hague 2016. 
używa się, nieprecyzyjnego i niekonsekwentnego, pojęcia usługi publiczne. I choć usługi te świadczone są odpłatnie, to odpłatność za usługę, którą ponosi usługobiorca nie uwzględnia pełnych kosztów jej wytworzenia. Innymi słowy, odpłatność w tym przypadku nie jest ustalana według kryterium zarobkowości, jakim kieruje się typowy przedsiębiorca, prowadzący działalność gospodarczą. Prowadzi to do oczywistej konstatacji, że usługi świadczone w ogólnym interesie gospodarczym nie byłyby zapewnione na rynku bez interwencji publicznej. Ewentualnie, jeśli byłyby świadczone - to na innych (gorszych) warunkach odnośnie do jakości usług, ich przystępności cenowej czy też powszechności dostępu dla beneficjentów ${ }^{16}$.

W przypadku usług świadczonych w ogólnym interesie gospodarczym na przedsiębiorcę-usługodawcę, któremu powierzony zostaje obowiązek świadczenia danej usługi, nakładany jest tzw. obowiązek użyteczności publicznej w zakresie usługi publicznej. W rezultacie, świadczenie usługi odbywa się na podstawie kryterium interesu ogólnego, to zaś gwarantuje, że realizacja usług będzie nie tylko zapewniona ale także, że ich świadczenie odbywać się będzie na pewnych szczególnych (specyficznych) zasadach. Ze względu na oczywisty kontekst gospodarczy świadczenia tych usług, a także skutki rynkowe, jakie one wywołują - usługi świadczone w ogólnym interesie gospodarczym objęte są zakresem europejskich regulacji prawnych dotyczących rynku wewnętrznego i reguł konkurencji ${ }^{17}$.

Do usług świadczonych $\mathrm{w}$ interesie ogólnym zalicza się również „usługi socjalne świadczone w interesie ogólnym” ${ }^{18}$ (social services of general interest). Są to usługi, które odgrywają niezwykle istotną rolę w życiu społecznym, przyczyniając się do ochrony grup zagrożonych ekskluzją społeczną. Opierając się na solidarności i równym dostępie, zaspokajają one potrzeby obywateli z najsłabszych grup społecznych. Z wymienionych powodów problematyka ich świadczenia jest jedną z najbardziej

${ }_{16}$ Zob. Komisja Europejska, Komunikat Komisji do Parlamentu Europejskiego, Rady, Europejskiego Komitetu Ekonomiczno-Społecznego i Komitetu Regionów - Ramy jakości dotyczące usług świadczonych w interesie ogólnym, Bruksela, dnia 20 grudnia 2011 r., KOM(2011) 900 wersja ostateczna, s. 4, EUR-Lex (dalej: Ramy Jakości).

17 Niemniej jednak możliwe są odstępstwa od tych zasad, jeśli konieczna jest ochrona dostępu obywateli do podstawowych usług.

18 Komisja Europejska, Ustugi socjalne świadczonew interesie ogólnym, https:/ / ec.europa. eu/info/topics/single-market/services-general-interest_pl [dostęp: 16.08.2019 r.]. 
wrażliwych politycznie, kontrowersyjnych i prawnie skomplikowanych tematów w UE ${ }^{19}$.

Wśród usług socjalnych świadczonych w interesie ogólnym ${ }^{20}$ tradycyjnie wyróżnia się, oprócz usług zdrowotnych, dwie grupy usług. Pierwszą, tworzą systemy zabezpieczenia społecznego o różnych formach organizacji (wzajemnych lub branżowych), pokrywające najistotniejsze z życiowych zagrożeń (w tym obejmujące: zdrowie, podeszły wiek, wypadki przy pracy, bezrobocie, emeryturę i niepełnosprawność $)^{21}$. Drugą grupę usług socjalnych świadczonych w interesie ogólnym stanowią tzw. „inne istotne usługi świadczone bezpośrednio osobom fizycznym". Usługi takie, co należy podkreślić, zapewniają zindywidualizowane wsparcie w zakresie włączenia społecznego. $W$ ten sposób osiągane są cele: prewencyjny i inkluzyjny oraz immanentnie przyporządkowanie usługom tego rodzaju. Staje się to oczywiste, zważywszy na najbardziej typowe rodzaje usług o charakterze socjalnym. Zaliczyć do nich można m.in. działania służące pomocy osobom fizycznym $\mathrm{w}$ zmaganiu się $\mathrm{z}$ bezpośrednimi życiowymi wyzwaniami czy kryzysami, takimi jak zadłużenie, utrata pracy, narkomania czy rozpad rodziny. Należą tu również działania, mające na celu

19 Na ten temat zob. U. Neergaard i in. (red.), Social Services of General Interest in the EU, The Hague 2013.

20 Wobec braku zdefiniowania pojęcia „usług socjalnych świadczonych w interesie ogólnym" zarówno w prawie pierwotnym, jak i wtórnym Unii Europejskiej, istotnych wskazówek interpretacyjnych odnośnie do sposobu ich pojmowania dostarcza komunikat Komisji Wspólnot Europejskich - Realizacja wspólnotowego programu lizbońskiego: Usługi socjalne użyteczności publicznej w Unii Europejskiej (Bruksela, dnia 26 kwietnia 2006 r., COM(2006) 177 wersja ostateczna), do którego nawiązują również Ramy Jakości.

${ }^{21}$ Przewodnik dotyczący stosowania przepisów prawa Unii Europejskiej z zakresu pomocy państwa, zamówień publicznych i rynku wewnętrznego do usług świadczonych w ogólnym interesie gospodarczym, w szczególności do usług socjalnych świadczonych w interesie ogólnym. Dokument roboczy służb Komisji, Bruksela, dnia 29 kwietnia 2013 r., SWD(2013) 53/2 wersja ostateczna, s. 27 (dalej: Przewodnik). Dokument, o którym mowa - jak stwierdza się w jego treści - zawiera „wyjaśnienia natury technicznej, przede wszystkim $\mathrm{w}$ oparciu o zwięzłe i czasem uproszczone streszczenia prawodawstwa i orzecznictwa z zakresu pomocy państwa, zamówień publicznych i rynku wewnętrznego, a w odniesieniu do problematyki pomocy państwa, również decyzji Komisji dotyczących usług świadczonych w ogólnym interesie gospodarczym, w szczególności usług socjalnych świadczonych w interesie ogólnym", Przewodnik, s. 22. Należy jednak wyraźnie podkreślić, że dokument ten, nie ma mocy wiążącej w stosunku do Komisji Europejskiej jako instytucji, lecz nie umniejsza to jego istotnej roli w zakresie aspektów aplikacyjnych dotyczących rozwiązań z obszaru usług świadczonych w interesie ogólnym. 
zapewnienie osobom zainteresowanym umiejętności społecznych, niezbędnych do pełnej integracji (np. rehabilitacja, nauka języków dla imigrantów), a w szczególności użytecznych na rynku pracy (szkolenia zawodowe i reintegracja zawodowa). Wyróżnić tu można również działania służące zintegrowaniu osób o długoterminowych potrzebach, wynikających np. z problemów ze zdrowiem czy też związanych z niepełnosprawnością. Wreszcie, do charakteryzowanej grupy zaliczyć należy również mieszkalnictwo socjalne, zapewniające lokum osobom w trudnym położeniu ekonomicznym ${ }^{22}$.

Powyższe przykłady potwierdzają, że usługi socjalne świadczone w interesie ogólnym mogą mieć zarówno charakter gospodarczy, jak i niegospodarczy. Jest to o tyle istotne, że niekiedy błędnie kwalifikuje się usługi socjalne świadczone w interesie ogólnym wyłącznie jako usługi o charakterze nieekonomicznym (nierynkowym) ${ }^{23}$.

Odnośnie do usług socjalnych świadczonych w interesie ogólnym należy także podkreślić, że choć odgrywają współcześnie coraz ważniejszą rolę, a popyt na nie wzrasta, to możliwości ich sfinansowania stają się coraz bardziej ograniczone. U podstaw takiego stanu rzeczy znajdują się różne czynniki. Niewątpliwie istotne znaczenie wśród nich odgrywają zmiany koninktury gospodarczej (w tym okresy kryzysu gospodarczego). Jednak na szczególną uwagę zasługuje pewien kluczowy czynnik, jakim jest starzenie się społeczeństwa ${ }^{24}$. Świadomość powyższych czynników i zjawisk legła u podstaw przyjęcia przez Komisję Europejską strategii wspierania jakości usług socjalnych w całej UE. W jej realizacji istotną rolę odegrało tworzenie i upowszechnienie narzędzi służących określaniu standardów oraz pomiaru, oceny i poprawy jakości usług socjalnych, a także stworzenie dobrowolnych europejskich ram jakości dla usług socjalnych. Te ostatnie, ze względu na konieczność zapewnienia ich stosowania w różnych państwach członkowskich, zostały opracowane w sposób uwzględniający krajowe strategie w zakresie jakości i zarazem zapewniające dużą ich elastyczność odnośnie do usług socjalnych charakterystyczną dla państw członkowskich.

${ }^{22}$ Zob. tamże, s. 27-28.

23 Na tę kwestię zwraca uwagę m.in. P. Bauby, zob. tenże, Unity and Diversity of SSGIs in the European Union, [w:] U. Neergaard i in. (red.), Social Services of General Interest..., s. 28-29.

${ }^{24}$ Zob. Ramy Jakości, s. 14. 
Trzecią kategorią usług kwalifikowanych jako usługi świadczone $\mathrm{w}$ interesie ogólnym stanowią „usługi o charakterze nieekonomicznym” (non-economic services). Ich charakter zdecydowanie różni się od wcześniej charakteryzowanych kategorii usług. Do kategorii tej zalicza się bowiem całkowicie fundamentalne dla organizacji i funkcjonowania państwa działania o charakterze systemowym. W szczególności do kategorii usług o charakterze nieekonomicznym zaliczyć należy: działalność policji, wymiaru sprawiedliwości czy też systemy zabezpieczenia społecznego. Elementem istotnym i zarazem wyróżniającym tę kategorię spośród innych usług jest fakt, iż nie podlegają one regułom rynku wewnętrznego i konkurencji, ani też żadnemu szczególnemu europejskiemu prawodawstwu.

\section{Wymagania związane $\mathrm{z}$ zapewnieniem usług świadczonych w interesie ogólnym}

Z dotychczasowych analiz wynika, że usługi świadczone w interesie ogólnym stanowią kategorię zbiorczą, do której zaliczyć należy zarówno usługi posiadające charakter ekonomiczny (gospodarczy), jak i nieposiadające takiego charakteru usługi o charakterze nieekonomicznym. Jedne i drugie łączy to, że - jako służące dobru ogółu - podlegają tzw. „szczególnym obowiązkom w zakresie świadczenia usług publicznych" 25 .

${ }^{25}$ Zob. Ramy Jakości, s. 3. Komisja Europejska podjęła inicjatywę zebrania kompleksowego zestawu działań, które są realizowane w sprawie usług świadczonych w interesie ogólnym i wyrażenia ich w formie dokumentu (tj. Ramy Jakości) określającego jednolite ramy dla przedmiotowych usług. Działanie to podyktowane było uznaniem szczególnej roli, jaką mają do spełnienia usługi świadczone w interesie ogólnym dla realizacji kluczowych wartości z punktu widzenia funkcjonowania UE. Abstrahując od kompleksowej analizy tego dokumentu uwagę należy zwrócić na kilka kluczowych kwestii. Rozpocząć należy od wskazania, że podstawowym celem dokumentu było określenie ram jakości, które wypełniają trzy obszary działań. Po pierwsze, działania legislacyjne służące poprawie przejrzystości i pewności prawa odnośnie do sposobu stosowania regulacji prawa unijnego do usług świadczonych w ogólnym interesie gospodarczym oraz ewentualnemu przeprowadzeniu zmian stanu prawnego, jeśli by się okazało konieczne dla zapewnienia szczególnych potrzeb. Po drugie, działania projakościowe - związane z promowaniem odpowiedniej jakości, w szczególności w dziedzinie usług socjalnych (społecznych) ukierunkowanych na realizację szczególnie istotnych potrzeb, co zarazem winno zostać następnie wykorzystane jako wzorzec (model) dla innych usług świadczonych w interesie 
Wymienione tu cechy usług świadczonych w interesie ogólnym, wymagają dalszej analizy, mającej na celu wskazanie: wymagań jakie są związane ze świadczeniem usług publicznych (w tym zwłaszcza powszechności dostępu, standardu jakościowego i cenowego) oraz praktyki funkcjonowania usług świadczonych w interesie ogólnym.

Analizę wymagań, jakie są związane ze świadczeniem usług publicznych warto rozpoczać od wskazania istoty znaczeniowej wyrażenia „podleganie szczególnym obowiązkom w zakresie świadczenia usług publicznych". W doktrynie wskazuje się, że chodzi tu o takie obowiązki, których świadczący je przedsiębiorca nie może modyfikować. Obowiązki te mają bowiem charakter podstawowy. Oznacza to, że w istocie mamy do czynienia z obowiązkami (zadaniami) państwa, których niepowierzenie do świadczenia konkretnemu przedsiębiorcy, skutkowałoby zobowiązaniem państwa do ich wykonania ${ }^{26}$.

Obecnie przyjmuje się, że państwa członkowskie UE dysponują szerokim marginesem uznaniowości odnośnie do określania, organizowania i finansowania usług świadczonych w interesie ogólnym. Co za tym idzie, należy przyjąć, że poszczególnym usługom świadczonym w interesie ogólnym $\mathrm{w}$ poszczególnych państwach członkowskich może być przyznany różny status organizacyjno-finansowy, jak i odmienny zakres ich świadczenia. Nie ma zatem jednego, uniwersalnego prawnego modelu zaspokajania w ten sposób potrzeb użytkowników.

Niezależnie jednak od tych możliwych, uzasadnionych, a niekiedy wręcz koniecznych różnic, przyjętych w prawodawstwie poszczególnych państw członkowskich, szczególny charakter usług świadczonych w interesie ogólnym przejawia się w tym, że mają być one dostępne dla wszystkich beneficjentów (tzn. dla ogółu konsumentów, użytkowników itp.). Co istotne, owa powszechność dostępu ma być zapewniona niezależnie od okoliczności (takich jak miejsce zamieszkania beneficjenta), zaś sposób ich świadczenia musi gwarantować odpowiednią jakość i - z uwzględnieniem szczególnych warunków panujących w danym państwie - przystępną cenę.

ogólnym. Po trzecie, działania zapewniające najpełniejszy dostęp wszystkich obywateli do podstawowych usług poprzez stworzenie odpowiednich ku temu narzędzi. Szerzej na ten temat zob. Ramy Jakości, s. 6-16.

26 Zob. K. Strzyczkowski, Prawo gospodarcze publiczne, s. 142. 
Właśnie ten ostatni element - przystępność cenowa - wymaga uwagi. W debacie publicznej, a także w pracach instytucji unijnych dość często łączy się problematykę dostępności usług z kwestią ich świadczenia na warunkach finansowych, możliwych do przyjęcia dla wszystkich beneficjentów. Pomóc w tym mają w szczególności programy zbiorowej i indywidualnej pomocy społecznej, które stosuje się (w różnej skali i zakresie) w poszczególnych państwach członkowskich. Jednak pomimo ich stosowania, dostępność do wielu podstawowych usług w praktyce napotyka na poważne problemy (zwłaszcza natury ekonomicznej).

Analizując dokumenty unijne można precyzyjnie wskazać, że dziedzinami, w których problemy te występują z największym nasileniem są zwłaszcza: mieszkalnictwo, łączność elektroniczna, transport, opieka zdrowotna, usługi społeczne, a także dostępność energii i wody ${ }^{27}$. Źródła takiego stanu rzeczy nie są jednorodne. Można wręcz wskazać na cały szereg czynników, odmiennie kształtujących się w poszczególnych państwach członkowskich. Przede wszystkim, istotną rolę mogą tu odgrywać historyczne uwarunkowania przyjętych modeli świadczenia usług w poszczególnych państwach członkowskich (często zasadniczo odmienne). Na tego typu „endemiczne uwarunkowania” nałożyć należy szereg dodatkowych, takich jak czynniki: gospodarcze (wysoka, nieprzystępna cena), geograficzne (brak faktycznego świadczenia usługi na pewnym obszarze), społeczne (nierówność traktowania obywateli w dostępie do usługi), fizyczne (utrudnienia $w$ dostępie do usługi, np. ze względu na niepełnosprawność), a także związane z niedostosowaniem usług do potrzeb obywateli (nieodpowiednia, zbyt niska, jakość czy niewystarczający poziom bezpieczeństwa $)^{28}$.

W kontekście powyższych analiz warto zauważyć, że usługom świadczonym $\mathrm{w}$ ogólnym interesie gospodarczym odpowiada $\mathrm{w}$ istocie koncepcja "usług podstawowych" wyrażona w Europejskim filarze praw socjalnych (Zasada nr 20) ${ }^{29}$. Na gruncie tego aktu są one traktowane jako zasadniczy element sprawiedliwości społecznej, opierający się na zasadzie równego traktowania użytkowników, zakazujący wszelkiego rodzaju

27 Zob. pkt 2.1.3 Opinii TEN/517.

28 Zob. pkt 2.2 Opinii TEN/517.

${ }^{29}$ KomisjaEuropejska,20zasadeuropejskiegofilaruprawsocjalnych,https://ec.europa.eu /commission/priorities/deeper-and-fairer-economic-and-monetary-union/european-pillar-social-rights/european-pillar-social-rights-20-principles_pl [dostęp: 16.08.2019 r.]. 
dyskryminacji lub wykluczenia oraz - co warte podkreślenia - na zasadzie powszechnego dostępu, obejmującego wysoki poziom przystępności cenowej oraz jakości ${ }^{30}$.

Pomimo, iż powszechność dostępu, przystępność cenowa oraz jakość usług tworzą trzy podstawowe wyznaczniki obecnego modelu usług świadczonych $\mathrm{w}$ interesie ogólnym, to stan prawodawstwa unijnego, normującego te kwestie jest wysoce niewystarczający. Uwidacznia się to w zasadzie w odniesieniu do każdego z wymienionych elementów. I tak, co do powszechności dostępu, istnieje przede wszystkim podstawowa potrzeba wyjaśnienia „koncepcji powszechnego dostępu do usług”31. Jest ona coraz wyraźniej dostrzegana i wyrażana w oficjalnych dokumentach organów doradczych UE. Kwestię tę podnosi m.in. Europejski Komitet Ekonomiczno-Społeczny, który w swojej Opinii TEN/692 z dnia 19 czerwca 2019 r. wyraża ją wprost, a ponadto akcentuje konieczność wprowadzenia środków legislacyjnych, zobowiązujących państwa członkowskie do wyznaczenia odpowiednich wskaźników, na podstawie których da się zwymiarować powszechny dostęp do poszczególnych usług. To stanowisko zasługuje na jednoznaczną aprobatę, biorąc pod uwagę fakt, że dopiero prawny obowiązek określenia wskaźników powszechnego dostępu ${ }^{32}$, pozwoli uniknąć sytuacji swoistej pozorności jego powszechności ${ }^{33}$.

W przywołanej Opinii TEN/ 692 znalazły się również - zasługujące na uznanie i uwypuklenie - ważne ustalenia co do przystępności cenowej oraz jakości usług. Mianowicie, Europejski Komitet Ekonomiczno-Społeczny, wskazując na zmianę, jaka dokonała się na przestrzeni lat w zakresie

30 Zob. pkt 1.3 opinii Europejskiego Komitetu Ekonomiczno-Społecznego (EKES), Lepsze wdrażanie filaru praw socjalnych oraz promowanie podstawowych usług, TEN/692-EESC-2019, przyjęta dnia 19 czerwca 2019 r., https://www.eesc.europa.eu/pl/ node/67812 (dalej: Opinia TEN/692).

31 W Opinii TEN/692 EKES zaleca konkretne działania odnoszące się co prawda do usług świadczonych w ogólnym interesie gospodarczym, niemniej jednak można je rozciągnąć na wszystkie kategorie usług świadczonych w interesie ogólnym.

${ }^{32}$ Wskazując np. gęstość punktów dostępu do usługi, maksymalna odległość od punktu dostępu, regularność świadczenia usług itp.

33 EKES akcentuje, że w szczególności na obszarach podmiejskich, wiejskich czy też o niskiej gęstości zaludnienia podstawowe usługi użyteczności publicznej (np. usługi pocztowe, usługi transportu publicznego) nie są należycie świadczone użytkownikom. W praktyce są często likwidowane lub niewystarczająco utrzymywane, a jeśli do tego dojdzie - nie zapewnia się równoważnych rozwiązań alternatywnych. 
podejścia do przystępności cenowej (w uproszczeniu: w miejsce wcześniej promowanej koncepcji „rozsądnej” taryfy socjalnej, postuluje się odpowiednio dobrane instrumenty pomocy społecznej dla osób najuboższych) oraz na fakt, że osoby najuboższe wciąż mają poważne trudności ekonomiczne $\mathrm{w}$ dostępie do usług, sformułował postulat by określenie przystępności dokonało się poprzez wyznaczenie koszyka usług, uznanych za podstawowe ${ }^{34}$. Stanowisko to jest niewątpliwie zasadne, choć jego skuteczność uzależniona będzie każdorazowo od charakteru prawnego takiego zobowiązania. Biorąc pod uwagę dotychczasowe problemy, jakie ujawniły się w związku z powszechną dostępnością usług wydaje się, że konieczne jest ustanowienie w tym zakresie prawnego obowiązku stworzenia koszyka usług podstawowych.

Z kolei, w odniesieniu do jakości usługi, Europejski Komitet Ekonomiczno-Społeczny domaga się, by państwa członkowskie wyznaczyły dla usług odpowiednie wskaźniki satysfakcji. Ustanowienie wskaźników jakościowych, takich jak: szybkość, punktualność, dostępność, kompetencja usługodawców czy ich gotowość do pomocy, mogą być skutecznym instrumentem przeciwdziałania niskiej jakości usług ${ }^{35}$.

Warto wreszcie zwrócić uwagę na jeszcze jeden istotny element analizy dotychczasowego funkcjonowania usług świadczonych w interesie ogólnym. Otóż, wskazywana wcześniej specyfika, związana ze świadczeniem tego rodzaju usług, w tym zwłaszcza wielość składających się na nie kategorii usług, ich gospodarczy lub niegospodarczy charakter i - ergo - wywoływane przez nie skutki rynkowe, a także ewolucja usług znajdująca odzwierciedlenie $w$ zmianach regulacji prawnych, wreszcie różnorodność rozwiązań, dotyczących ich świadczenia w poszczególnych państwach członkowskich - wymagają systematycznej i kompleksowej ewaluacji, zarówno w perspektywie unijnej, jak i w perspektywie rozwiązań, przyjmowanych w poszczególnych państwach członkowskich. Jedynie systematyczne, bieżące badanie usług pozwoli na ocenę efektywności

34 Jednocześnie wyrażone zostało stanowisko, że „stopień wysiłku finansowego gospodarstwa domowego dla każdej z usług powinien się opierać na poziomie akceptowalnym w odniesieniu do świadczenia socjalnego/minimalnego wynagrodzenia, powyżej którego ceny są zawyżone i wymagają zastosowania środków regulacyjnych bądź dają prawo do pomocy publicznej".

35 Takich jak wskazywane przez EKES m.in: opóźnienia (odwołania) w transporcie publicznym, nieodpowiedni lub niewystarczający zasięg terytorialny dla łączności elektronicznej itp. 
ich świadczenia - weryfikację, czy osiągane są założone cele, co z kolei pozwoli na usprawnienie i ulepszenie modelu świadczenia usług. Jedynie podejmowanie takich działań znajdzie przełożenie na wzrost skuteczności owego modelu.

Biorąc pod uwagę obiektywną zmienność elementów (np. dostępnych technologii), kształtujących sposób świadczenia usług, konieczne jest systematyczne dokonywanie bieżącego badania zarówno istniejących obowiązków w zakresie usługi publicznej, jak i ewentualnego zapotrzebowania na wprowadzenie nowych obowiązków. Jest to uzasadnione, gdyż państwa członkowskie zachowują swobodę co do rozszerzenia istniejących obowiązków w zakresie usługi publicznej lub wprowadzenia nowych obowiązków (rzecz jasna pod warunkiem, że środki te są zgodne $\mathrm{z}$ prawem unijnym $)^{36}$ i mogą tym samym reagować na zmieniające się okoliczności.

Co więcej, kwestia bieżącego badania sposobu funkcjonowania usług świadczonych w interesie ogólnym ma do odegrania ważną rolę w kontekście problemu równoważenia potrzeby zwiększenia konkurencji (a co za tym idzie stosowania mechanizmów rynkowych), z koniecznością zagwarantowania, by każdy obywatel miał zapewniony dostęp do wysokiej jakości podstawowych usług po przystępnych cenach. Brak bieżącego badania - zarówno odnośnie do pozytywnych skutków ich stosowania (takich jak: ograniczenie cen, dywersyfikacja podaży), jak i negatywnych (takich jak: wzrost cen, tworzenie oligopoli, strategia „spijania śmietanki", zwiększenie zatrudnienia na niepewnych warunkach, dumping socjalny) - uniemożliwi całościową ocenę polityki liberalizacji usług świadczonych w ogólnym interesie gospodarczym. W szczególności, niezwykle potrzebna jest weryfikacja sytuacji, w przypadku których wprowadzenie konkurencji usług przyczyniło się do postępu gospodarczego, społecznego czy też do umacniania więzi społecznych, a gdzie natomiast wprowadzenie konkurencji, doprowadziło do wzrostu taryf lub do ograniczenia misji służby publicznej ${ }^{37}$.

\footnotetext{
36 Zob. Ramy Jakości, s. 10-11.

37 Zob. pkt 4 Opinii TEN/692.
} 


\section{Zakończenie}

Klasyfikacja usług świadczonych w interesie ogólnym (obejmująca trzy wskazane wcześniej kategorie usług: usługi świadczone w ogólnym interesie gospodarczym, usługi socjalne świadczone w interesie ogólnym oraz usługi o charakterze nieekonomicznym) nie odzwierciedla, niezwykle istotnego - z punktu widzenia wspólnego rynku - czynnika, jakim jest charakter ekonomiczny poszczególnych usług. Z perspektywy tego ostatniego, czy też z punktu widzenia kryterium „logiki handlowej”, możliwe jest wyróżnienie dwóch podstawowych rodzajów (grup) usług: świadczonych w ogólnym interesie gospodarczym oraz o charakterze nieekonomicznym świadczonych w interesie ogólnym. Z tym dychotomicznym podziałem wiążą się określone skutki prawne. Jeśli chodzi o usługi świadczone w ogólnym interesie gospodarczym, to - ze względu na wskazane kryterium "logiki handlowej” - podlegają one unijnym zasadom konkurencji i rynku wewnętrznego (o ile tylko nie stanowi to przeszkody w wypełnianiu ich szczególnych funkcji i wynikających z nich zadań). Z kolei, usługi o charakterze nieekonomicznym świadczone w interesie ogólnym - jako niepodporządkowane "logice handlowej" - nie podlegają zasadom rynkowym i w konsekwencji należą do wyłącznej kompetencji państw członkowskich.

Mimo że usługi świadczone w interesie ogólnym, a także składające się na nie poszczególne kategorie usług, mają już ugruntowaną i niekwestionowaną pozycję jako istotne elementy europejskiego modelu społecznego, to wciąż obecny jest problem braku jasności pojęć, celów i zadań związanych $\mathrm{z}$ realizacją tych usług. Pomimo że usługi świadczone $\mathrm{w}$ interesie ogólnym stanowią swoistą konstrukcję prawa unijnego, a ich niedookreślenie $\mathrm{w}$ prawodawstwie unijnym jest zabiegiem celowym, to coraz częściej formułowany jest postulat precyzyjnego zdefiniowania pojęć, celów i zadań wszystkich usług świadczonych w interesie ogólnym (zarówno gospodarczych, jak i pozagospodarczych). Stanowisko takie jest dyskusyjne, w szczególności w kontekście potencjalnego ograniczania swobody ustawodawstwa poszczególnych państw członkowskich nie tylko dotyczącego definiowania, ale przede wszystkim odnośnie do kwalifikowania określonych usług do poszczególnych kategorii.

Wszystkie usługi świadczone $\mathrm{w}$ interesie ogólnym (niezależnie od tego, czy są to usługi świadczone w ogólnym interesie gospodarczym, czy też usługi o charakterze nieekonomicznym świadczone w interesie 
ogólnym) mają zapewnić (zagwarantować) wszystkim mieszkańcom dostęp do nich jako istotny element ochrony praw podstawowych. Jest to wyrazem dążenia UE do spójności gospodarczej, społecznej i terytorialnej. Z tej perspektywy, zasadnym wydaje się stworzenie zharmonizowanej unijnej metodyki oceny usług świadczonych w interesie ogólnym, która byłaby oparta na wspólnych wskaźnikach. Dokonywana w ten sposób miarodajna i pozbawiona uznaniowości ocena, mogłaby skutecznie przyczyniać się do zapewnienia obywatelom jak najlepszej jakości usług świadczonych w interesie ogólnym. Oczekiwanie to jest uzasadnione na gruncie unijnego prawodawstwa, a jego adresatem są zarówno instytucje krajowe, jak i unijne. Skuteczna ocena mogłaby de lege ferenda stać się integralną częścią europejskiego modelu społecznego.

Słowa kluczowe: usługi świadczone w ogólnym interesie gospodarczym, usługi o charakterze nieekonomicznym, usługi socjalne świadczone w interesie ogólnym

\section{Bibliografia}

\section{Źródła}

\section{Akty prawne}

Traktat z Lizbony zmieniający Traktat o Unii Europejskiej i Traktat ustanawiający Wspólnotę Europejską, sporządzony w Lizbonie dnia 13 grudnia 2007 r., Dz. U. z 2009 r. Nr 203, poz. 1569.

Traktat o funkcjonowaniu Unii Europejskiej (wersja skonsolidowana), Dz. Urz. UE C 326 z 26.10.2012, s. 47-200.

\section{Dokumenty}

Komisja Wspólnot Europejskich, Zielona Księga na temat usług użyteczności publicznej, Bruksela, dnia 21 maja 2003 r., Green Paper on Services of General Interest, COM(2003) 270 wersja ostateczna - Official Journal C 76 z 25.03.2004.

Komisja Wspólnot Europejskich, Komunikat Komisji do Parlamentu Europejskiego, Rady, Komitetu Ekonomiczno-Społecznego oraz Komitetu Regionów Biała księga nt. usług użyteczności publicznej, Bruksela, dnia 12 maja 2004 r., COM(2004) 374 wersja ostateczna (nieopublikowany w Dzienniku Urzędowym), EUR-Lex. 
Komisja Wspólnot Europejskich, Komunikat Komisji - Realizacja wspólnotowego programu lizbońskiego: Usługi socjalne użyteczności publicznej w Unii Europejskiej, Bruksela, dnia 26 kwietnia 2006 r., COM(2006) 177 wersja ostateczna, EUR-Lex.

Komisja Europejska, Komunikat Komisji do Parlamentu Europejskiego, Rady, Europejskiego Komitetu Ekonomiczno-Społecznego i Komitetu Regionów Ramy jakości dotyczące usług świadczonych w interesie ogólnym, Bruksela, dnia 20 grudnia 2011 r., KOM(2011) 900 wersja ostateczna, EUR-Lex.

Przewodnik dotyczący stosowania przepisów prawa Unii Europejskiej z zakresu pomocy państwa, zamówień publicznych i rynku wewnętrznego do usług świadczonych w ogólnym interesie gospodarczym, w szczególności do usług socjalnych świadczonych w interesie ogólnym. Dokument roboczy służb Komisji, Bruksela, dnia 29 kwietnia 2013 r., SWD(2013) 53/2 wersja ostateczna.

Europejski Komitet Ekonomiczno-Społeczny, Przystępność usług świadczonych w ogólnym interesie gospodarczym: definicja, pomiar, aspekty, inicjatywy europejskie, TEN/517 [opinia], Bruksela, dnia 21 stycznia 2014 r., http:// www.eesc.europa.eu.

Europejski Komitet Ekonomiczno-Społeczny, Lepsze wdrażanie filaru praw socjalnych oraz promowanie podstawowych usług TEN/692-EESC-2019 [opinia], przyjęta dnia 19 czerwca 2019 r., https://www.eesc.europa.eu/pl/ node/67812.

\section{Literatura}

Bauby P., Unity and Diversity of SSGIs in the European Union, [w:] U. Neergaard $\mathrm{i}$ in. (red.), Social Services of General Interest in the EU, The Hague-Berlin 2013.

Cała-Wacinkiewicz E., Charakter prawny Unii Europejskiej w świetle prawa międzynarodowego, Warszawa 2007.

Izdebski H., Samorząd terytorialny. Podstawy ustroju i działalności, Warszawa 2011.

Komisja Europejska, Ustugi socjalne świadczone w interesie ogólnym, https:// ec.europa.eu/info/topics/single-market/services-general-interest_pl [dostęp: 16.08.2019 r.].

Krajewski M., U. Neergaard, J. van de Gronden (red.), The Changing Legal Framework for Services of General Interest in Europe. Between Competition and Solidarity, The Hague 2009.

Krajewski M. (red.), Services of General Interest Beyond the Single Market. External and International Law Dimensions, The Hague 2015.

Strzyczkowski K., Prawo gospodarcze publiczne, Warszawa 2011.

Wehlander C., Services of General Economic Interest as a Constitutional Concept of EU Law, The Hague 2016. 


\section{SERVICES OF GENERAL INTEREST AS A PART OF THE EUROPEAN SOCIAL MODEL}

\section{Sum mary}

The current political, economic and social situation in the European Union has highlighted the fundamental role of services of general interest. Three categories of services are classified as being of general interest and, therefore, subject to specific public service obligations: services of general economic interest (basic services that are carried out in return for payment); non-economic services (such as the police or justice); social services of general interest (based on the principles of solidarity and equal access). In areas such as childcare or care for the elderly, health care or support to disabled persons, those services provide an essential tool for citizens' safety. Services of general interest also play a key role in social cohesion.

Key words: services of general economic interest, non-economic services, social services of general interest

\section{УСЛУГИ, ПРЕДОСТАВЛЯЕМЫЕ В ИНТЕРЕСАХ ОБЩЕСТВА КАК ЧАСТЬ ЕВРОПЕЙСКОЙ СОЦИАЛЬНОЙ МОДЕЛИ}

\section{Резюме}

Современная политическая, экономическая и социальная ситуация подчеркнула решающую роль услуг, предоставляемых в интересах общества в Европейском Союзе. Три категории услуг классифицируются как услуги, служащие общему благу и, следовательно, подлежат определенным обязательствам: Услуги, предоставляемые в экономических интересах общества (основные платные услуги); услуги неэкономического характера (такие как, например, деятельность полиции или системы правопорядка); социальные услуги, предоставляемые в интересах общества (основанные на принципах солидарности и равного доступа). В таких областях, как опека над детьми или опека над людьми преклонного возраста, здравоохранение или помощь людям с ограниченными возможностями, эти услуги являются важным инструментом обеспечения безопасности граждан. Услуги, предоставляемые в интересах общества также играют ключевую роль в социальной сплоченности.

Ключевые слова: Услуги, предоставляемые в экономических интересах общества; Услуги неэкономического характера; Социальные, предоставляемые в экономических интересах общества 
